\title{
Correction to: Smallholder coffee producer's perception to climate change and variability: the evidence from Mana district, South Western Ethiopia
}

\author{
Alemu Tesfaye $(\mathbb{D} \cdot$ Abayineh Amare $\cdot$ Guta Regasa Megerssa
}

Published online: 27 February 2022

(C) Springer Nature B.V. 2022

\section{Correction to: GeoJournal}

https://doi.org/10.1007/s10708-021-10537-9

The first (corresponding) author mistakenly left out the names of the co-authors who contributed to this manuscript. Individual author contributions are as follows:

1. Alemu Tesfaye (First/corresponding author): Research design, data collection, data coding, data cleaning, data analysis, report writing and manuscript preparation.
2. Abayineh Amare (Second author): Research design, data analysis, report writing and preparation of the manuscript.

3. Guta Regasa Megerssa (Third author): Research design, data analysis, report writing and preparation of the manuscript.

Publisher's Note Springer Nature remains neutral with regard to jurisdictional claims in published maps and institutional affiliations.
The original article can be found online at https:// doi.org/10.1007/s10708-021-10537-9.

A. Tesfaye $(\bowtie)$

Department of Agricultural Economics, College of Agriculture and Natural Resource, Mizan-Tepi

University, Mizan-Aman, Ethiopia

e-mail: alemutesfaye710@gmail.com

A. Amare - G. R. Megerssa

Department of Rural Development and Agricultural Extension, College of Agriculture and Veternary

Medicine, Jimma University, Jimma, Ethiopia 